\title{
The significance of folic acid, tissue iron stores, and tissue viability in determining iron uptake from serum by thyroid tissue slices
}

\author{
W. M. BUCHANAN \\ From the Department of Pathology, University College of Rhodesia, Harari Hospital, Salisbury
}

SYNOPSIS This paper describes an attempt to measure in vitro iron uptake from serum by human thyroid slices and to relate the uptake to tissue iron stores, folic acid status, and tissue viability It is an extension of work previously reported (Buchanan, 1969).

Thyroids were obtained from patients undergoing partial thyroidectomy for colloid goitre ando serum from clinically normal healthy adults. The haemoglobin, serum iron, and folic acid levels of both thyroid and serum donors were measured and thyroids examined histologically for the presence of stainable iron. Viable and non-viable tissue slices were incubated in sera treated with radioactive iron so as to produce high and normal levels of transferrin saturation.

Iron was taken up both from sera with normal and high transferrin saturation but the amount was, in almost all cases, greater from the more highly saturated.

The uptake by non-viable tissue was appreciable but did not vary to any great extent from one serum to the next, and was attributed to simple diffusion of ionic iron into the tissue. There was, however, marked variation in uptake from different sera by viable tissue. It was concluded therefore that viability is a factor affecting the uptake. As the variation in uptake by viable tissue incubated in a single serum was significantly less than tissue incubated in a number of different seraㄹ it was further concluded that there was also a factor in the serum itself affecting iron uptake. The $e_{5}$ nature of the factor was not elucidated but neither folic acid nor levels of iron stores appeared teक influence uptake because no correlation was found between iron uptake and iron stores or folic acid

In iron overload due to haemochromatosis heavy deposits of iron are invariably present in a wide variety of epithelial tissues (Sheldon, 1935), while in Bantu siderosis epithelial iron deposits are usually restricted to the liver despite there being comparable amounts of excess iron in each condition (Higginson, Gerritsen, and Walker, 1953).

The factors which determine the uptake of iron by tissues from the blood have not yet been completely elucidated. It has been shown that when various samples of human tissue obtained at operation are incubated in autologous serum the iron uptake is partly dependent on the degree of transferrin saturation (Buchanan, 1969). It was found that the uptake of iron by all the tissues examined was greater from sera whose transferrin was $90 \%$ saturated than from that in which the transferrin was only $50 \%$ saturated. A high level of transferrin Received for publication 3 September 1970. saturation was not the only determining factor because there was a considerable variation in uptake between samples of the same tissue taken from differ- ent individuals. The reason for this variation is not clear. It was noted that in one liver sample. containing very heavy deposits of haemosiderin the uptake was small while in another from a patient with iron-deficiency anaemia the uptake was pronounced, suggesting that the variation in uptakev might in some way be related to the level of tissue iron stores. Elsewhere, animal experiments have indicated that serum folic acid levels are important in determining iron uptake by tissues (MacDonald? Jones, and Pechet, 1965).

\section{Material and Methods}

Thyroid was used in this investigation because of its ready availability and because it is known to take up 
iron well (Buchanan, 1969). In all cases partial thyroidectomy had been performed for colloid goitre. Samples were taken from areas which grossly most closely resembled normal thyroid while foci of degeneration and haemorrhage were avoided. Areas adjacent to those used for the tests were examined histologically. The sections were stained by haematoxylin and eosin and Perls's method for iron (Pearse, 1961).

Measurements were made of the haemoglobin (cyanmethaemoglobin method, Dacie and Lewis, 1968), serum iron (S.I.) (Bothwell and Mallet, 1955), unsaturated iron-binding capacity (Bothwell, Jacobs, and Kamener, 1959), and serum folic acid (Waters and Mollin, 1961). The normal range for folic acid in this laboratory has been found to be $3-15 \mathrm{ng} / \mathrm{ml}$.

The serum was prepared by pipetting $8 \mathrm{ml}$ aliquots into polythene tubes in pairs. The procedure followed then was exactly as described in the previous paper (Buchanan, 1969), that is, solutions containing ${ }^{59} \mathrm{Fe}$ were added to the sera to produce $50 \%$ saturation of the transferrin in one tube and $90 \%$ saturation in the second.

The tissue specimens were cut at a thickness of $0.5 \mathrm{~mm}$ and incubated in the sera for three hours. After washing in Krebs-Ringer solution the specimens were dried on blotting paper and weighed to the nearest milligram. They were then digested in nitric acid and the radioactivity of each was measured. The iron uptake was calculated and expressed as micrograms iron per $100 \mathrm{mg}$ wet weight of tissue.

Thyroids from seven patients were examined. From the thyroid of each patient 20 aliquots of tissue each weighing between 90 and $110 \mathrm{mg}$ were prepared. Ten of the aliquots were placed in tubes with transferrin $50 \%$ saturated and 10 in tubes with transferrin $90 \%$ saturated.
The first thyroid was used to test the accuracy of the method by incubating the aliquots of tissue in tubes all containing serum from the same donor. Thereafter, specimens of each thyroid were incubated in sera from 10 different donors.

Thyroid tissue was used either immediately after operation or after it had been allowed to stand for 24 hours at $+4^{\circ} \mathrm{C}$. It was assumed that the thyroid incubated immediately remained viable for the period of the experiment while that which had been stored in the refrigerator was not viable.

Localization of absorbed iron in the tissues was sought by making autoradiographs of three pairs of samples following incubation in sera. After tissues had been incubated, rinsed, and dried small portions were set aside for histology while the balance was digested as described. Histological sections were cut at $4 \mu$ in a cryostat. The sections were fixed in dried formalin vapour for $\mathbf{4 8}$ hours. They were then rinsed in distilled water and autoradiographs made using Ilford G 5 liquid emulsion with an exposure of three weeks.

\section{Results}

The values for haemoglobin, serum iron, and serum

\begin{tabular}{llllll}
\hline $\begin{array}{l}\text { Thyroid } \\
\text { Number }\end{array}$ & Sex & Age & $\begin{array}{l}\mathrm{Hb} \\
(\mathrm{g} / 100 \mathrm{ml})\end{array}$ & $\begin{array}{l}\text { Serum Iron } \\
(\mu \mathrm{g} / 100 \mathrm{ml})\end{array}$ & $\begin{array}{l}\text { Folic } \\
\text { Acid } \\
(\mathrm{ng} / \mathrm{ml})\end{array}$ \\
\hline 1 & $\mathrm{M}$ & 32 & $13 \cdot 3$ & 126 & 3.8 \\
2 & $\mathrm{M}$ & 24 & 14.6 & 112 & $5 \cdot 7$ \\
3 & $\mathrm{M}$ & 25 & 14.8 & 141 & 6.6 \\
4 & F & 60 & $12 \cdot 8$ & 123 & 8.8 \\
5 & F & 24 & 14.1 & 139 & 4.2 \\
6 & F & 25 & 13.4 & 109 & 9.7 \\
7 & F & 32 & 15.1 & 112 & 3.9 \\
\hline
\end{tabular}

Table I Clinical data of thyroid donors

\begin{tabular}{|c|c|c|c|c|c|c|}
\hline \multirow{2}{*}{$\begin{array}{l}\text { Serum } \\
\text { Number }\end{array}$} & \multicolumn{3}{|c|}{ Serum Donor } & \multicolumn{2}{|c|}{ Uptake of Iron from Transferrin } & \multirow{2}{*}{$\begin{array}{l}\text { Difference } \\
\text { in } \\
\text { Uptake }\end{array}$} \\
\hline & $\begin{array}{l}\mathrm{Hb} \\
(\mathrm{g} / 100 \mathrm{ml})\end{array}$ & $\begin{array}{l}S I \\
(\mu g / 100 \mathrm{ml})\end{array}$ & $\begin{array}{l}F A \\
(n g / m l)\end{array}$ & $\begin{array}{l}\text { Approximately } \\
50 \% \text { Saturated }\end{array}$ & $\begin{array}{l}\text { Approximately } \\
90 \% \text { Saturated }\end{array}$ & \\
\hline 1 & $15 \cdot 8$ & 120 & $\begin{array}{r}3 \cdot 2 \\
\text { Range } \\
\text { Mean } \\
\text { Standard deviation }\end{array}$ & $\begin{array}{l}0.042 \\
0.045 \\
0.048 \\
0.043 \\
0.049 \\
0.040 \\
0.041 \\
0.039 \\
0.044 \\
0.045 \\
0.039-0.049 \\
0.044 \\
0.003\end{array}$ & $\begin{array}{l}0.301 \\
0 \cdot 330 \\
0 \cdot 312 \\
0 \cdot 310 \\
0 \cdot 390 \\
0 \cdot 356 \\
0 \cdot 290 \\
0.381 \\
0 \cdot 322 \\
0 \cdot 364 \\
0 \cdot 290-0.390 \\
0.330 \\
0.034\end{array}$ & $\begin{array}{l}0.259 \\
0 \cdot 295 \\
0 \cdot 264 \\
0 \cdot 267 \\
0 \cdot 341 \\
0 \cdot 316 \\
0 \cdot 349 \\
0 \cdot 342 \\
0 \cdot 278 \\
0 \cdot 319 \\
0 \cdot 259-0.349 \\
0 \cdot 293 \\
0.034\end{array}$ \\
\hline
\end{tabular}

Table II Iron uptake by a viable thyroid (no. 1) from 10 samples of a single serum ${ }^{1}$

${ }^{1}$ Results expressed in $\mu_{\mathrm{g}} \mathrm{Fe} / 100 \mathrm{mg}$ wet weight of tissue. 
folic acid of thyroid donors are given in Table I. No thyroid donor was suffering from iron-deficiency anaemia or folic acid deficiency. Histological examination of the thyroids in no case revealed any stainable iron. It is unlikely that appreciable iron overload was present in any of the thyroid donors, except possibly in the woman of 60 years, as in Rhodesian Africans marked siderosis is uncommon in males under 30 and females under 40 years (Buchanan, 1966 and 1967).

Table II gives the iron uptake by viable thyroid samples incubated in aliquots of a single serum indicating a high degree of reproducibility of the method.

In Table III the iron uptake by a non-viable thyroid from 10 different sera is shown. The particularly small standard deviation of the differences in uptake compared with the standard deviations at $50 \%$ and $90 \%$ saturation considered separately suggest that a factor within the different sera is exerting a con- siderable effect on the variation in uptake at the different levels.

Table IV shows the iron uptake by five different viable thyroids, aliquots of each being incubated in 10 different sera. Except for a very few cases the? uptake of iron by the tissues was greater from transferrin $90 \%$ saturated than from transferrin $50 \%$ saturated. Each thyroid showed a fairly wide $\stackrel{\odot}{\complement}$ range in uptake from the various sera with a $50 \%$ saturation of transferrin, though in cases 3,5 , and $\vec{\theta}$ 6 this range was much greater than in cases 4 and 7. In three instances the uptake at this degree of satu- $\vec{\omega}$ ration was notably high, being more than 0.200 o $\mu \mathrm{g} / 100 \mathrm{mg}$ tissue. Each of these high uptakes in $-\frac{8}{8}$ volved different thyroids.

Autoradiographs showed radioactivity in sections from both degrees of transferrin saturation and that the ${ }^{59} \mathrm{Fe}$ was largely concentrated in the $\infty$ epithelial cells. The distribution was patchy through-은 out the sections, some follicles showing much -

\begin{tabular}{|c|c|c|c|c|c|c|}
\hline \multirow{2}{*}{$\begin{array}{l}\text { Serum } \\
\text { Number }\end{array}$} & \multicolumn{3}{|c|}{ Serum Donor } & \multicolumn{2}{|c|}{ Uptake of Iron from Transferrin } & \multirow{2}{*}{$\begin{array}{l}\text { Difference } \\
\text { in } \\
\text { Uptake }\end{array}$} \\
\hline & $\begin{array}{l}\mathrm{Hb} \\
(\mathrm{g} / 100 \mathrm{ml})\end{array}$ & $\begin{array}{l}S I \\
(\mu \mathrm{g} / 100 \mathrm{ml})\end{array}$ & $\begin{array}{l}F A \\
(n g / m l)\end{array}$ & $\begin{array}{l}\text { Approximately } \\
50 \% \text { Saturated }\end{array}$ & $\begin{array}{l}\text { Approximately } \\
90 \% \text { Saturated }\end{array}$ & \\
\hline 2 & $13 \cdot 7$ & 102 & $4 \cdot 1$ & 0.037 & $0 \cdot 147$ & $0 \cdot 110$ \\
\hline 3 & $12 \cdot 2$ & 68 & $8 \cdot 1$ & 0.050 & $0 \cdot 170$ & $0 \cdot 120$ \\
\hline 4 & $10 \cdot 7$ & 68 & $7 \cdot 4$ & 0.044 & $0 \cdot 150$ & $0 \cdot 106$ \\
\hline 5 & $13 \cdot 2$ & 70 & $3 \cdot 8$ & 0.084 & $0 \cdot 194$ & 0.110 \\
\hline 6 & $14 \cdot 1$ & 108 & $9 \cdot 4$ & 0.051 & $0 \cdot 155$ & $0 \cdot 104$ \\
\hline 7 & $14 \cdot 7$ & 70 & $6 \cdot 2$ & 0.011 & $0 \cdot 118$ & $0 \cdot 107$ \\
\hline 8 & $15 \cdot 2$ & 71 & $6 \cdot 6$ & 0.057 & $0 \cdot 163$ & $0 \cdot 106$ \\
\hline 9 & $16 \cdot 0$ & 122 & $5 \cdot 3$ & 0.081 & $0 \cdot 187$ & $0 \cdot 106$ \\
\hline 10 & $14 \cdot 8$ & 90 & $2 \cdot 6$ & 0.089 & $0 \cdot 196$ & $0 \cdot 107$ \\
\hline \multirow[t]{4}{*}{11} & $16 \cdot 3$ & 71 & $7 \cdot 1$ & 0.041 & $0 \cdot 140$ & 0.099 \\
\hline & & & Range & $0.011-0.089$ & $0 \cdot 118-0 \cdot 196$ & $0.699-0 \cdot 120$ \\
\hline & & & Mean & 0.054 & $0 \cdot 162$ & $0 \cdot 107$ \\
\hline & & & Standard deviation & 0.024 & 0.025 & $0 . \operatorname{CC} 6$ \\
\hline
\end{tabular}

Table III Iron uptake by a non-viable thyroid (no. 2) from 10 different sera $^{1}$

${ }^{1}$ Results expressed in $\mu \mathrm{g} \mathrm{Fe} / 100 \mathrm{mg}$ wet weight of tissue.

\begin{tabular}{|c|c|c|c|c|c|c|}
\hline \multirow{2}{*}{$\begin{array}{l}\text { Serum } \\
\text { Number }\end{array}$} & \multicolumn{3}{|c|}{ Serum Donor } & \multicolumn{2}{|c|}{ Uptake of Iron from Transferrin } & \multirow{2}{*}{$\begin{array}{l}\text { Difference } \\
\text { in } \\
\text { Uptake }\end{array}$} \\
\hline & $\begin{array}{l}\mathrm{Hb} \\
(\mathrm{g} / 100 \mathrm{ml})\end{array}$ & $\begin{array}{l}S I \\
(\mu g / 100 \mathrm{nl})\end{array}$ & $\begin{array}{l}F A \\
(n g / m l)\end{array}$ & $\begin{array}{l}\text { Approximately } \\
50 \% \text { Saturated }\end{array}$ & $\begin{array}{l}\text { Approximately } \\
90 \% \text { Saturated }\end{array}$ & \\
\hline $\begin{array}{l}12 \\
13 \\
14 \\
15 \\
16 \\
17 \\
18 \\
19 \\
20 \\
21\end{array}$ & $\begin{array}{l}16.0 \\
12.6 \\
12.0 \\
13.4 \\
13.0 \\
15.2 \\
13.7 \\
14.1 \\
15.0 \\
13.7\end{array}$ & $\begin{array}{r}140 \\
144 \\
45 \\
140 \\
106 \\
97 \\
132 \\
160 \\
65 \\
80\end{array}$ & $\begin{array}{rr}7 \cdot 5 & \\
4 \cdot 4 & \\
5 \cdot 7 & \\
6 \cdot 6 & \\
9 \cdot 0 & \\
4 \cdot 0 & \\
3 \cdot 6 & \\
5 \cdot 3 & \\
5 \cdot 7 & \\
6 \cdot 0 & \text { Range } \\
& \text { Mean } \\
& \\
\text { Standard deviation }\end{array}$ & $\begin{array}{l}0.012 \\
0.111 \\
0.330 \\
0.017 \\
0.019 \\
0.029 \\
0.010 \\
0.013 \\
0.028 \\
0.089 \\
0.010-0.330 \\
0.066 \\
0.120\end{array}$ & $\begin{array}{l}0.014 \\
0 \cdot 280 \\
2 \cdot 260 \\
0 \cdot 177 \\
0.019 \\
0.020 \\
0.015 \\
0.017 \\
0.350 \\
0.093 \\
0.014-2 \cdot 260 \\
0.325 \\
0.690\end{array}$ & $\begin{array}{l}0.002 \\
0.169 \\
1.930 \\
0.160 \\
0.000 \\
-0.009 \\
0.005 \\
0.004 \\
0.322 \\
0.004 \\
0.009-1.930 \\
0.259 \\
0.597\end{array}$ \\
\hline
\end{tabular}

Table IVa Iron uptake by viable thyroid (no. 3) from different sera ${ }^{1}$

${ }^{1}$ Results expressed in $\mu \mathrm{g} \mathrm{Fe} / 100 \mathrm{mg}$ wet weight of tissue. 
activity while others showed none (Fig. 1). Activity in sections from the highly saturated transferrin was more extensive and intense than that from transferrin $50 \%$ saturated. Nevertheless, in localized areas of sections from the latter follicles showed fairly marked activity (Fig. 2).

\begin{tabular}{|c|c|c|c|c|c|c|}
\hline \multirow{2}{*}{$\begin{array}{l}\text { Serum } \\
\text { Number }\end{array}$} & \multicolumn{3}{|c|}{ Serum Donor } & \multicolumn{2}{|c|}{ Uptake of Iron from Transferrin } & \multirow{2}{*}{$\begin{array}{l}\text { Difference } \\
\text { in } \\
\text { Uptake }\end{array}$} \\
\hline & $\begin{array}{l}H b \\
(\mathrm{~g} / 100 \mathrm{ml})\end{array}$ & $\begin{array}{l}S I \\
(\mu g / 100 \mathrm{ml})\end{array}$ & $\begin{array}{l}F A \\
(n g / m l)\end{array}$ & $\begin{array}{l}\text { Approximately } \\
50 \% \text { Saturated }\end{array}$ & $\begin{array}{l}\text { Approximately } \\
90 \% \text { Saturated }\end{array}$ & \\
\hline $\begin{array}{l}22 \\
23 \\
24 \\
25 \\
26 \\
27 \\
28 \\
29 \\
30 \\
31\end{array}$ & $\begin{array}{l}13.0 \\
14.8 \\
15.2 \\
13.7 \\
14.2 \\
13.4 \\
12.6 \\
13.4 \\
12.8 \\
12.8\end{array}$ & $\begin{array}{r}86 \\
72 \\
160 \\
100 \\
128 \\
116 \\
50 \\
80 \\
80 \\
146\end{array}$ & $\begin{array}{rr}6 \cdot 8 & \\
2 \cdot 2 & \\
6 \cdot 7 \\
8 \cdot 9 \\
3 \cdot 8 \\
9 \cdot 6 \\
5 \cdot 1 \\
3 \cdot 4 \\
4 \cdot 8 \\
7 \cdot 4 \\
& \\
& \text { Range } \\
\text { Standard deviation }\end{array}$ & $\begin{array}{l}0.018 \\
0.048 \\
0.022 \\
0.030 \\
0.011 \\
0.025 \\
0.026 \\
0.028 \\
0.035 \\
0.025 \\
0.011-0.048 \\
0.027 \\
0.010\end{array}$ & $\begin{array}{l}0.025 \\
0.231 \\
0.023 \\
0.120 \\
0.854 \\
0.021 \\
0.035 \\
0.140 \\
0.240 \\
0.025 \\
0.021-0.854 \\
0.171 \\
0.255\end{array}$ & $\begin{array}{l}0.007 \\
0.183 \\
0.001 \\
0.090 \\
0.843 \\
-0.004 \\
0.009 \\
0.112 \\
0.205 \\
0.000 \\
0.004-0.183 \\
0.145 \\
0.257\end{array}$ \\
\hline
\end{tabular}

Table IVb Iron uptake by viable thyroid (no. 4) from different sera

\begin{tabular}{|c|c|c|c|c|c|c|}
\hline \multirow{2}{*}{$\begin{array}{l}\text { Serum } \\
\text { Number }\end{array}$} & \multicolumn{3}{|c|}{ Serum Donor } & \multicolumn{2}{|c|}{ Uptake of Iron from Transferrin } & \multirow{2}{*}{$\begin{array}{l}\text { Difference } \\
\text { in } \\
\text { Uptake }\end{array}$} \\
\hline & $\begin{array}{l}\mathrm{Hb} \\
(\mathrm{g} / 100 \mathrm{ml})\end{array}$ & $\begin{array}{l}S I \\
(\mu \mathrm{g} / 100 \mathrm{ml})\end{array}$ & $\begin{array}{l}F A \\
(n g / m l)\end{array}$ & $\begin{array}{l}\text { Approximately } \\
50 \% \text { Saturated }\end{array}$ & $\begin{array}{l}\text { Approximately } \\
90 \% \text { Saturated }\end{array}$ & \\
\hline $\begin{array}{l}32 \\
33 \\
34 \\
35 \\
36 \\
37 \\
38 \\
39 \\
40 \\
41\end{array}$ & $\begin{array}{l}12.7 \\
13.0 \\
11.8 \\
14.5 \\
12.6 \\
14.0 \\
12.9 \\
13.7 \\
13.0 \\
11.4\end{array}$ & $\begin{array}{r}100 \\
104 \\
82 \\
104 \\
151 \\
96 \\
108 \\
122 \\
100 \\
92\end{array}$ & $\begin{array}{rr}2 \cdot 8 & \\
7 \cdot 4 & \\
5 \cdot 0 & \\
6 \cdot 0 & \\
5 \cdot 8 & \\
3 \cdot 4 & \\
9 \cdot 4 & \\
9 \cdot 8 & \\
5 \cdot 7 & \\
3 \cdot 8 & \\
& \text { Range } \\
& \text { Mean } \\
\text { Standard deviation }\end{array}$ & $\begin{array}{l}0.005 \\
0.043 \\
0.003 \\
0.240 \\
0.012 \\
0.005 \\
0.030 \\
0.009 \\
0.050 \\
0.050 \\
0.003-240 \\
0.045 \\
0.071\end{array}$ & $\begin{array}{l}0.043 \\
0.056 \\
0.003 \\
0.254 \\
0.020 \\
0.007 \\
0.057 \\
0.010 \\
0.140 \\
0.094 \\
0.003-0.254 \\
0.068 \\
0.104\end{array}$ & $\begin{array}{l}0.038 \\
0.013 \\
0.000 \\
0.014 \\
0.008 \\
0.002 \\
0.027 \\
0.001 \\
0.090 \\
0.044 \\
0.000-0.090 \\
0.024 \\
0.028\end{array}$ \\
\hline
\end{tabular}

Table IVc Iron uptake by viable thyroid (no. 5) from different sera

\begin{tabular}{|c|c|c|c|c|c|c|}
\hline \multirow{2}{*}{$\begin{array}{l}\text { Serum } \\
\text { Number }\end{array}$} & \multicolumn{3}{|c|}{ Serum Donor } & \multicolumn{2}{|c|}{ Uptake of Iron from Transferrin } & \multirow{2}{*}{$\begin{array}{l}\text { Difference } \\
\text { in } \\
\text { Uptake }\end{array}$} \\
\hline & $\begin{array}{l}\mathrm{Hb} \\
(\mathrm{g} / 100 \mathrm{ml})\end{array}$ & $\begin{array}{l}S I \\
(\mu g / 100 \mathrm{ml})\end{array}$ & $\begin{array}{l}F A \\
(n g / m l)\end{array}$ & $\begin{array}{l}\text { Approximately } \\
50 \% \text { Saturated }\end{array}$ & $\begin{array}{l}\text { Approximately } \\
90 \% \text { Saturated }\end{array}$ & \\
\hline $\begin{array}{l}42 \\
43 \\
44 \\
45 \\
46 \\
47 \\
48 \\
49 \\
50 \\
51\end{array}$ & $\begin{array}{l}12.2 \\
11.0 \\
15.2 \\
12.1 \\
13.0 \\
11.8 \\
12.6 \\
13.7 \\
14.8 \\
14.8\end{array}$ & $\begin{array}{r}60 \\
111 \\
140 \\
44 \\
60 \\
32 \\
112 \\
59 \\
136 \\
84\end{array}$ & $\begin{array}{rr}2 \cdot 2 & \\
2 \cdot 6 & \\
4 \cdot 2 & \\
5 \cdot 8 & \\
3 \cdot 8 & \\
3 \cdot 4 & \\
3 \cdot 5 & \\
5 \cdot 4 & \\
4 \cdot 0 & \\
4 \cdot 6 & \text { Range } \\
& \begin{array}{r}\text { Mean } \\
\end{array} \\
\text { Standard deviation }\end{array}$ & $\begin{array}{l}0.042 \\
0.012 \\
0.020 \\
0.041 \\
0.042 \\
0.042 \\
0.053 \\
0.504 \\
0.023 \\
0.041 \\
0.012-0.504 \\
0.082 \\
0.148\end{array}$ & $\begin{array}{l}0 \cdot 103 \\
0 \cdot 440 \\
0 \cdot 053 \\
0 \cdot 136 \\
0 \cdot 190 \\
0 \cdot 213 \\
0 \cdot 130 \\
1 \cdot 141 \\
0 \cdot 051 \\
0.083 \\
0 \cdot 051-1 \cdot 141 \\
0 \cdot 254 \\
0.332\end{array}$ & $\begin{array}{l}0.061 \\
0.428 \\
0.033 \\
0.095 \\
0.148 \\
0.171 \\
0.077 \\
0.637 \\
0.028 \\
0.042 \\
0.028-0.638 \\
0.172 \\
0.202\end{array}$ \\
\hline
\end{tabular}

Table IVd Iron uptake by viable thyroid (no. 6) from different sera 


\begin{tabular}{|c|c|c|c|c|c|c|}
\hline \multirow{2}{*}{$\begin{array}{l}\text { Serum } \\
\text { Number }\end{array}$} & \multicolumn{3}{|c|}{ Serum Donor } & \multicolumn{2}{|c|}{ Uptake of Iron from Transferrin } & \multirow{2}{*}{$\begin{array}{l}\text { Difference } \\
\text { in } \\
\text { Uptake }\end{array}$} \\
\hline & $\begin{array}{l}\mathrm{Hb} \\
(\mathrm{g} / \mathrm{l} 00 \mathrm{ml})\end{array}$ & $\begin{array}{l}S I \\
(\mu \mathrm{g} / 100 \mathrm{ml})\end{array}$ & $\begin{array}{l}F A \\
(n g / m l)\end{array}$ & $\begin{array}{l}\text { Approximately } \\
50 \% \text { Saturated }\end{array}$ & $\begin{array}{l}\text { Approximately } \\
90 \% \text { Saturated }\end{array}$ & \\
\hline 52 & $11 \cdot 4$ & 74 & $2 \cdot 8$ & 0.055 & $0 \cdot 145$ & 0.090 \\
\hline 53 & $14 \cdot 5$ & 76 & $4 \cdot 2$ & 0.085 & 0.574 & 0.489 \\
\hline 54 & $12 \cdot 2$ & 86 & $9 \cdot 3$ & 0.055 & $0 \cdot 391$ & 0.336 \\
\hline 55 & $15 \cdot 1$ & 86 & $3 \cdot 0$ & 0.048 & 0.203 & $0 \cdot 155$ \\
\hline 57 & $13 \cdot 7$ & 80 & $5 \cdot 6$ & 0.052 & 0.069 & 0.017 \\
\hline 58 & $14 \cdot 5$ & 110 & $3 \cdot 6$ & 0.043 & 0.090 & 0.047 \\
\hline 59 & $14 \cdot 1$ & 82 & $5 \cdot 6$ & 0.073 & $0 \cdot 180$ & $0 \cdot 107$ \\
\hline 60 & $14 \cdot 8$ & 120 & $2 \cdot 0$ & 0.036 & $0 \cdot 166$ & $0 \cdot 130$ \\
\hline \multirow[t]{4}{*}{61} & $13 \cdot 8$ & 136 & $1 \cdot 6$ & 0.060 & $0 \cdot 126$ & 0.066 \\
\hline & & & Range & $0.029-0.085$ & $0.069-0.785$ & $0.017-0.756$ \\
\hline & & & Mean & 0.054 & $0 \cdot 273$ & 0.219 \\
\hline & & & Standard deviation & 0.058 & $0 \cdot 237$ & $0 \cdot 238$ \\
\hline
\end{tabular}

Table IVe Iron uptake by viable thyroid (no. 7) from different sera

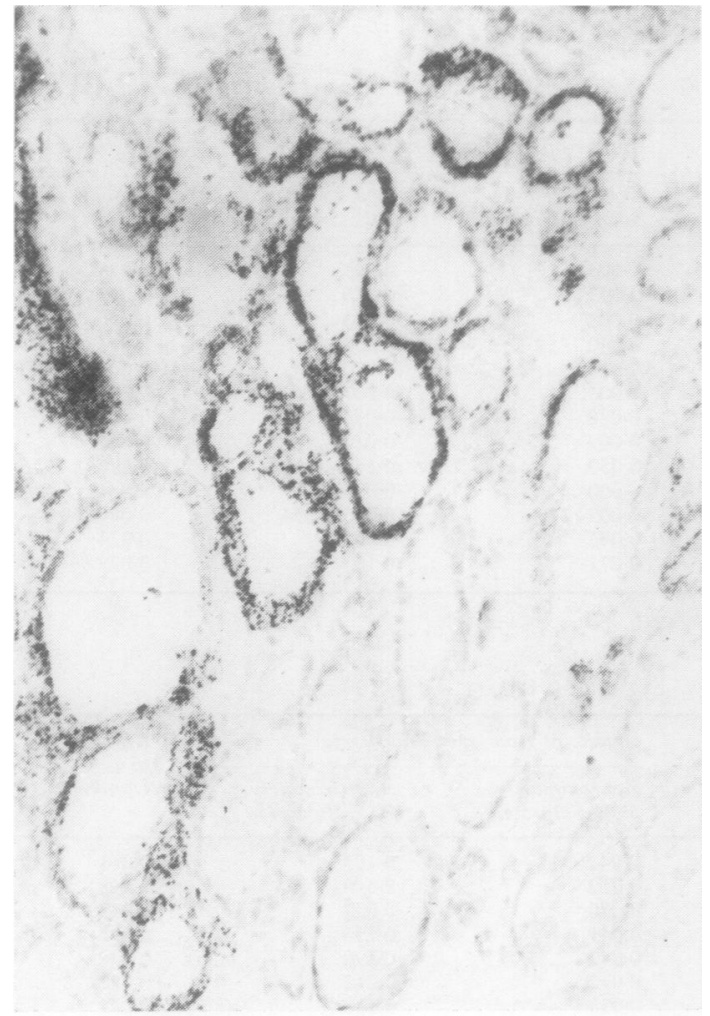

Fig. 1 This is an autoradiograph of thyroid 4 from serum 30 with transferrin $90 \%$ saturated. It shows that ${ }^{53} \mathrm{Fe}$ is almost entirely confined to the epithelial cells of the follicles. The patchy distribution of the iron uptake is also clearly seen. $(\times 125)$

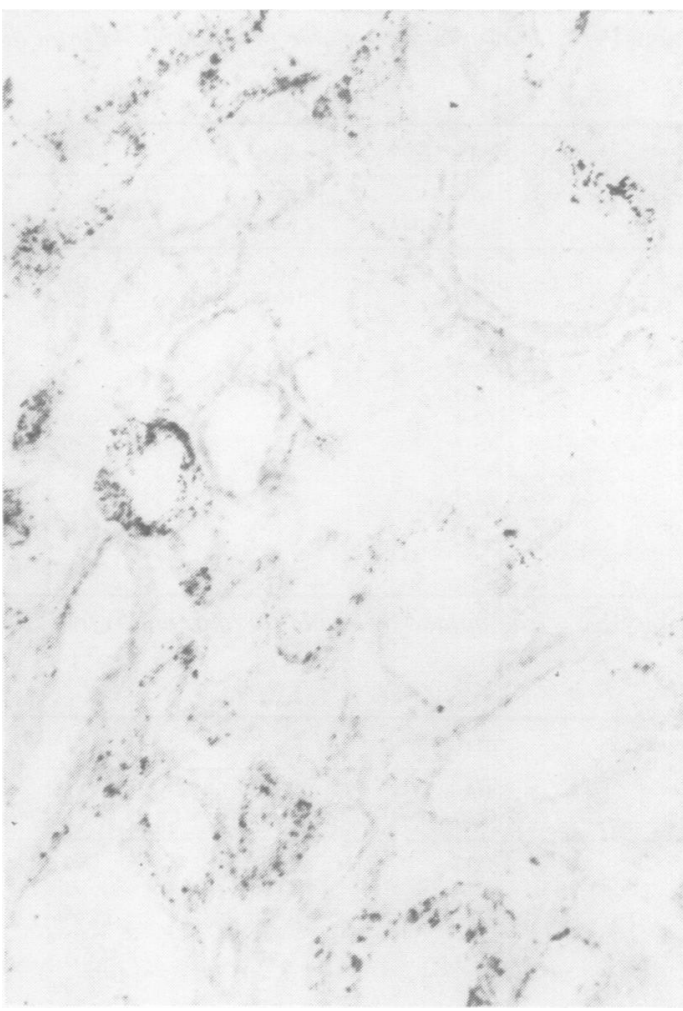

Fig. 2 This is an autoradiograph of the same thyroid and serum as in Fig. 1 but with transferrin $50 \%$ saturated. There is appreciably less uptake of ${ }^{59} \mathrm{Fe}$ than from transferrin $90 \%$ saturated. It also is confined to the epithelial cells. $(\times 125)$ 


\section{Discussion}

The results of this investigation confirm those already demonstrated that high percentage saturation of transferrin by iron is in some measure responsible for uptake of this element by thyroid tissue (Buchanan, 1969). While high degrees of transferrin saturation increase uptake in most cases it is clear that some uptake also occurs from transferrin only $50 \%$ saturated. In the previous study it was suggested that this uptake by tissues from transferrin $50 \%$ saturated was more apparent than real and might in fact be due to non-specific trapping of radioactive serum in the tissue during incubation (Buchanan, 1969). This explanation appears unlikely now, because if the uptake was only due to nonspecific trapping, one would expect that the variation in uptake by viable thyroids would be unaffected by the incubation in different sera. That this is not the case is shown by the fact that the variance for each thyroid in Table IV is statistically significantly greater than the variance of the one thyroid incubated repeatedly in the single serum in Table II $(0.01>$ p). Further confirmation that there is uptake of iron by epithelial cells from transferrin $50 \%$ saturated is provided by the autoradiographs. These show that the little radioactivity seen is almost entirely confined to the epithelial cells and that scanty activity is present in the interstitial tissue.

Rat liver slices accumulate iron when incubated in Krebs-Ringer solution containing ionic iron (Saltman, Fiskin, and Bellinger, 1956) and this accumulation of iron does not require metabolic energy (Saltman, Fiskin, Bellinger, and Alex, 1956). Mazur, Green, and Carleton (1960) have suggested that at high levels of saturation some iron is not firmly bound to transferrin and may therefore be in the ionic form. It is possible that to some extent iron uptake by tissues from highly saturated transferrin is due to diffusion of ionic iron into the cells rather than the result of an active process. Some support is given to this argument in the present study by the fact that there was an appreciable uptake by nonviable thyroid slices. The method of uptake by viable tissues, however, cannot be entirely by simple diffusion of ionic iron because the variances of uptake at $50 \%$ saturation, at $90 \%$ saturation, and of the differences in uptake in Table IV are significantly higher than for the non-viable thyroid in Table III $(P<0.01)$. Viability of the tissue would, therefore, appear to play some part in regulating iron uptake from serum.

In addition there must be some element in the serum which affects uptake because samples of the same thyroid took up different amounts of iron from different sera. Probably the viability factor and serum factor work in conjunction to depress uptake in some cases and enhance it in others.

No correlation could be shown between haemoglobin and serum iron values of serum donors and the uptake at either level of transferrin saturation or the difference in uptake. Also there was no evidence that any of the thyroid donors was suffering from iron deficiency or iron excess. This appears to indicate that it is unlikely that iron stores play any significant part in iron uptake by tissues from serum.

Some degree of folic acid deficiency was found in nine of the donors of sera. There was no correlation between folic acid levels of the incubation sera and the uptake of iron. Also none of the thyroid donors was folic acid deficient so it appears that iron uptake can still be considerable despite normal folic acid levels in recipient tissue. This is of particular interest, as, in rats, iron uptake by epithelial tissues other than liver occurs with high degrees of transferrin saturation only if there is concomitant folic acid deficiency (MacDonald et al, 1965).

I wish to thank the surgeons at Harari Hospital for providing thyroid tissue for this investigation: Mr N. Lyons, Mrs J. Atherston, and Mrs G. Herrington for technical assistance; Dr Winifred $M$. Castle for help in presenting statistical information; and Professor J. G. Cruickshank for helpful criticism of the script.

\section{References}

Bothwell, T. H., Jacobs, P., and Kamener, R. (1959). The determination of the unsaturated iron-binding capacity of serum using radioactive iron. S.Afr. J. med. Sci., 24, 93-98.

Bothwell, T. H., and Mallet, B. (1955). The determination of iron in plasma or serum. Biochem. J., 59, 599-602.

Buchanan, W. M. (1966). Siderosis in Rhodesian Africans. Cent. Afr. J. Med., 12, 199-207.

Buchanan, W. M. (1967). Bantu Siderosis with Special Reference to Rhodesian Africans. (Faculty of Medicine Research Lecture. Series no. 1.) University College of Rhodesia, Salisbury, Rhodesia.

Buchanan, W. M. (1969). Aetiology of extrahepatic epithelial iron deposits in siderosis in Bantu. J. clin. Path., 22, 296-300.

Dacie, J. V., and Lewis, S. M. (1968). Practical Haematology, p. 35. Churchill, London.

Higginson, J., Gerritsen, T., and Walker, A. R. P. (1953). Siderosis in the Bantu of Southern Africa. Amer. J. Path., 29, 779-815.

MacDonald, R. A., Jones, R. S., and Pechet, G. S. (1965). Folic acid deficiency and hemochromatosis. Arch. Path., 80, 153-160.

Mazur, A., Green, S., and Carleton, A. (1960). Mechanism of plasma iron incorporation into hepatic ferritin. J. biol. Chem., 235, 595-603.

Pearse, A. G. E. (1961). Histochemistry, 2nd ed. Churchill, London.

Saltman, P., Fiskin, R. D., and Bellinger, S. B. (1956). The metabolism of iron by rat liver slices. The effect of physical environment and iron concentration. J. biol. Chem., 220, 741-750.

Saltman, O., Fiskin, R. D., Bellinger, S. B., and Alex, T. (1956). The metabolism of iron by rat liver slices. The effect of chemical agents. J. biol. Chem., 220, 751-757.

Sheldon, J. H. (1935). Haemochromatosis. Oxford University Press, London.

Waters, A. H., and Mollin, D. L. (1961). Studies on the folic acid activity of human serum. J. clin. Path., 14, 335-344. 